\title{
Research on the development path of China's digital trade under the background of the digital economy
}

\author{
Boning Li and Su Zhang \\ Central University of Finance and Economics, Beijing, China
}

\begin{abstract}
Purpose - The purpose of this study is to explore how the development of digital trade can provide new development prospects to China's foreign trade under the background of the gradual expansion of China's digital economy and the further release of policy dividends.

Design/methodology/approach - Using the methods of literature collection and induction, combined with traditional trade theory, this paper analyzes the characteristics and challenges of digital trade under the background of the digital economy.

Findings - The findings reveal that China's digital trade development still faces some risks, such as the containment of China's core technology, digital security and unbalanced development among regions. Considering these risks, China should break through core technical problem, participate in the formulation of international rules to ensure data security, give priority to the development of service trade and improve the unbalanced development of digital trade.

Social implications - By analyzing the development status and characteristics of the digital economy and digital trade, this paper summarizes the challenges and comparative advantages faced by China's digital trade, and puts forward corresponding suggestions. These suggestions will allow China to take advantage of its rapid digital economy development and occupy a leading position in global digital trade.

Originality/value - This paper creatively expounds on the new development direction of digital trade from the perspective of comparative advantage and risks, and provides some suggestions to expedite China's digital trade development.
\end{abstract}

Keywords Digital economy, Digital trade, Development path

Paper type Research paper

\section{Introduction}

The rapid development of the global digital economy has influenced people's lives, as well as the industrial structures, scientific and technical innovation, and economic development of many countries. The digital economy is an important development direction for countries worldwide and a key driving force for global economic growth and innovation. It is also an important engine in encouraging high-quality development of China's economy and an important force in promoting the transformation and upgrade of traditional trade and the high-quality, sustainable development of foreign trade (Meijers, 2014; Pei et al., 2018; Liu et al., 2019).

Presently, the development degree of the digital economy differs in various countries, and China's development of the digital economy is at the global forefront. According to the "New Picture of Global Digital Economy (2020)," the scale of the digital economy in the USA ranks first, and China ranks second; there is still immense scope for development (see Figure 1). Digital resources, coupled with labor, capital, land and technology are indispensable elements

\section{JEL Classification - F14, F42}

(C) Boning Li and Su Zhang. Published in Journal of Internet and Digital Economics. Published by Emerald Publishing Limited. This article is published under the Creative Commons Attribution (CC BY 4.0) licence. Anyone may reproduce, distribute, translate and create derivative works of this article (for both commercial and non-commercial purposes), subject to full attribution to the original publication and authors. The full terms of this licence may be seen at http://creativecommons.org/licences/by/4.0/ legalcode.

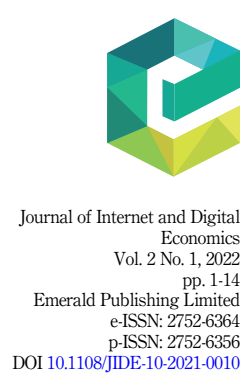

Received 13 October 2021 Revised 29 November 2021 Accepted 15 January 2022 
$\mathrm{JIDE}_{2,1}$

Figure 1.

Top 10 countries in digital economy scale in 2019

\section{(100 million USD)}

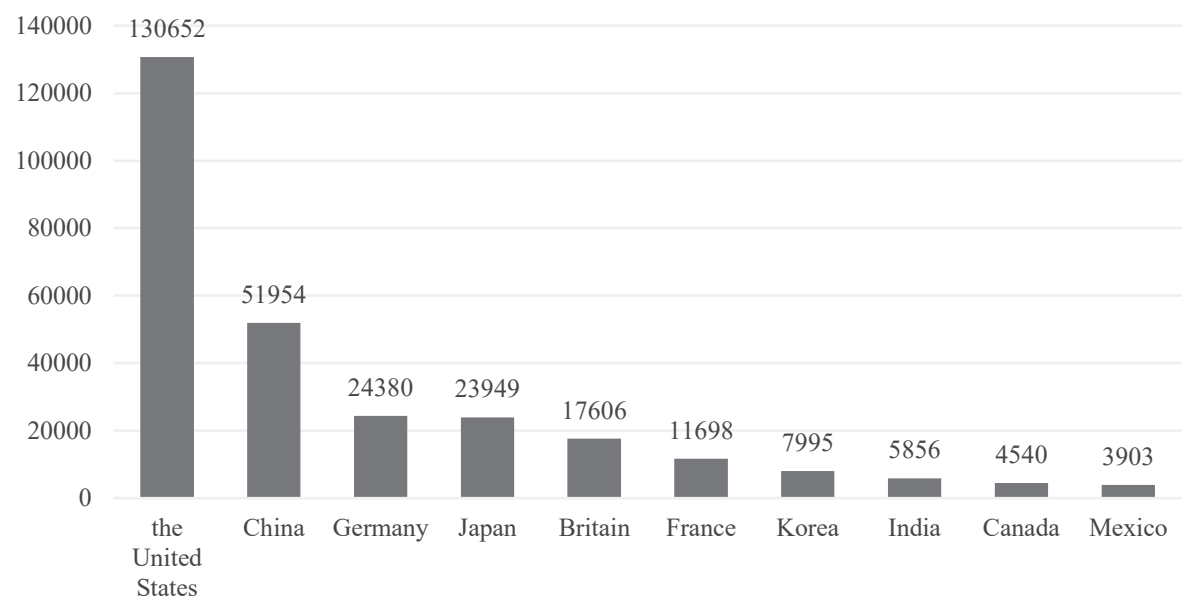

Note(s): Arranged according to the "New Picture of Global Digital Economy (2020)," released by CAICT

of China's high-quality economic development; they have become the core strategic resources of digital economy. Jing and Sun (2019) discussed the digital economy's path to promote economic development from the micro and macro perspectives, thereby highlighting that the digital economy can help match supply and demand, form a better price mechanism and improve the economic level. As an important economic development engine, the digital economy has also received full attention from the state and governments at all levels. The proposal in the "Suggestions of the CPC Central Committee on Formulating the 14th Five Year Plan for National Economic and Social Development and the Long-term Objectives for 2035" highlight the need to develop the digital economy and "create new advantages of the digital economy." Developing the digital economy is the internal requirement and an inevitable choice for unblocking dual circulation and realizing high-quality economic development under the new development pattern. Zhao et al. (2021) believed that the digital economy could stimulate domestic market demand and improve industrial support to strengthen trade ties and facilitate smooth dual circulation.

With the rapid rise of the global digital economy, China's foreign trade has also entered a new era. The in-depth integration of digital technology and international trade has accelerated the arrival of the digital trade era. Under the gradual development of China's digital economy, the impacts of trade disputes between China and the USA and COVID-19 also make China's foreign trade development situation extremely grim, such as facing the obstacles of trade channels, the increase of investment uncertainty and the aggravation of international financial market turbulence. Whether the threats faced by China's international trade can be overcome and resolved through the digital economy and digital trade development is an important issue of concern for the government and scholars. This paper will analyze the development status and characteristics of the digital economy and digital trade and explore the challenges faced by China under the development environment of the digital economy. Additionally, we will provide suggestions on how to leverage comparative advantages and promote high-quality development of digital trade. 


\section{Development status and characteristics of the digital economy}

The "digital economy" concept was first put forward in 1994 by Don Tapscott, known as "the father of digital economy." At present, the digital economy has become the main economic form and the core driving force of global industrial reform. In 2016, the G20 summit meeting defined the digital economy as "a series of economic activities with the use of digital knowledge and information as key production factors, modern information network as an important carrier, and the effective use of information and communication technology as an important driving force for efficiency improvement and economic structure optimization." With the promotion of trade exchanges at home and abroad and the integrated development of various industries, the digital economy has gradually penetrated real industries, which improves their output and production efficiency and becomes a new driving force and direction of economic innovation. In this context, the development of China's digital economy has several characteristics.

\subsection{The scale of China's digital economy is expanding day-by-day, ranking at the forefront of the world}

According to the "Statistical Bulletin of National Economic and Social Development of the People's Republic of China (2020)," the number of Internet users in China has reached 989 million, an increase of nearly $116 \%$ from the 457 million users recorded 10 years ago. China's rich Internet population resources have laid a solid foundation for the development of the digital economy. The "White Paper on the Development of China's Digital Economy (2020)" showed that the scale of China's digital economy increased sharply in the past 15 years, and its proportion in GDP also increased steadily, with an increase of nearly 12.7 times [1]. In 2011, the scale of the digital economy exceeded $20 \%$ of the GDP for the first time. In 2019, the growth of China's digital economy reached 35.8 trillion $\mathrm{RMB}$, accounting for a record-high proportion of the GDP. The contribution rate to economic growth reached $67.7 \%$, which means that China's digital economy is still developing continuously and rapidly. The digital economy occupies an important position in the national economy (see Figure 2). The "New Picture of Global Digital Economy (2020)" showed that in 2019, the growth rate of China's digital economy was higher than that of the GDP, and other countries show the same trend (see Figure 3). Moreover, the growth rate of "industrial digitization" is higher than that of "digital industrialization." Globally, China represents a large digital economy, and it has great potential in digital trade, digital information, digital industry and so on. The rapid growth of the digital economy scale is closely related to the continuous improvement of China's infrastructure, the continuous release of policy dividends, the vigorous development of new business forms and digital technology innovation.

\subsection{The dividend of digital economy policy related to foreign trade continued to release}

Since the 18th National Congress, general secretary Xi Jinping has attached great importance to developing the digital economy, and the top-level design has been gradually improved. The digital economy has been supporting policies intensively, and the municipal government has also been actively deployed from all aspects. In 2019, as many as 34 policies on the digital economy were issued at the national level, and 609 policies were issued by local governments, representing an increase of 2.36 times. Table 1 summarizes China's digital economy policies related to foreign trade, showing that multiple policy dividends have covered the digital economy's development, opening and supervision. With the continuous release of policy dividends, the digital economy and digital trade will drive a new economic development climax.

\subsection{The positive externality effect of the digital economy's development has gradually become prominent}

Zhang et al. (2019) found that digital finance can achieve inclusive growth by improving the entrepreneurial behavior of rural residents. Zhan and Ouyang (2018) pointed out that the digital 


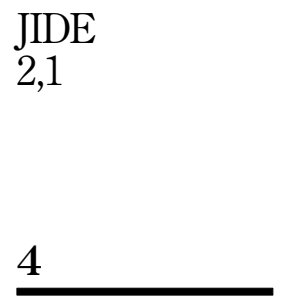

Figure 2.

Overview of China's digital economy from 2016 to 2019

\section{Figure 3.}

Global digital economic growth and GDP growth in 2019

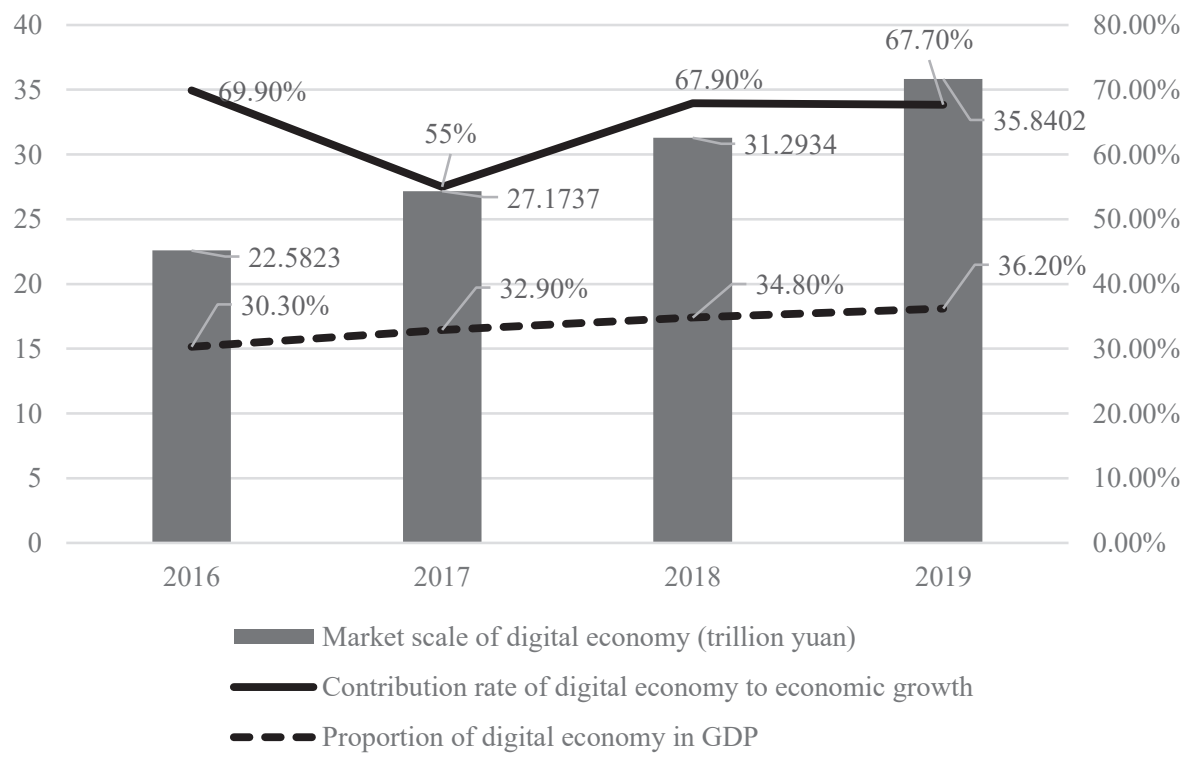

Note(s): Arranged according to the "New Picture of Global Digital Economy (2020)" and the "White Paper on the Development of China's Digital Economy (2020)," released by CAICT

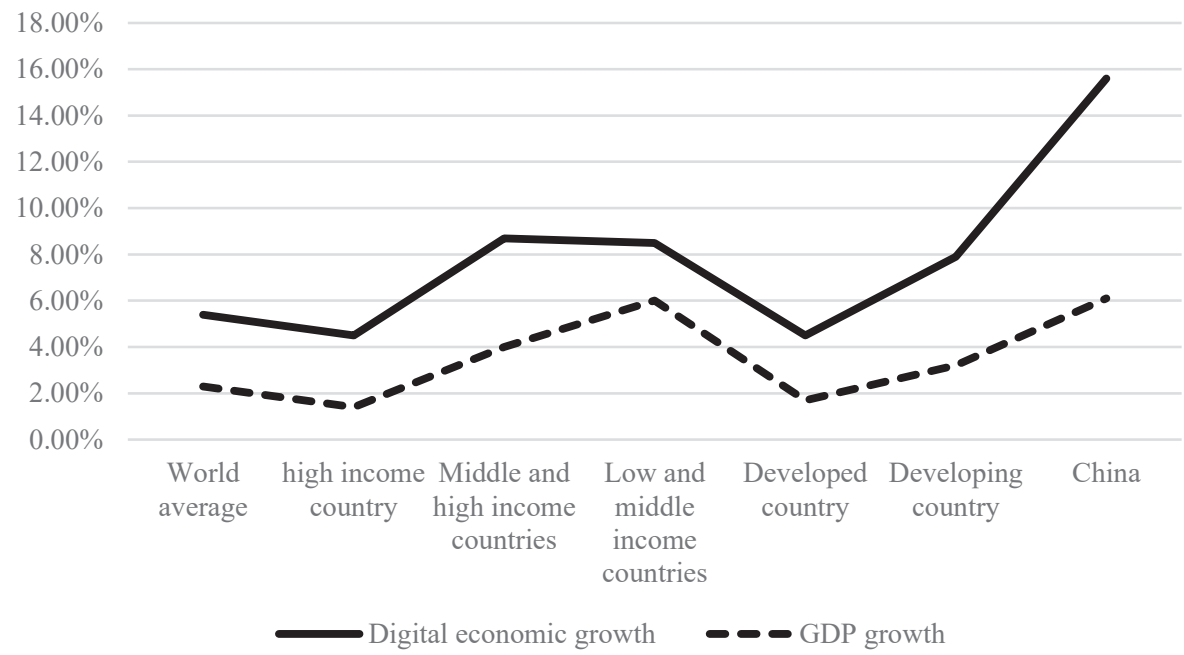

Note(s): Arranged according to the "New Picture of Global Digital Economy (2020)," released by CAICT, and the "Statistical Bulletin of National Economic and Social Development of the People's Republic of China (2020)," released by State Statistical Bureau 


\begin{tabular}{|c|c|c|c|}
\hline Time & Background & Content & \\
\hline 2015.12 & World Internet Conference 2015 & $\begin{array}{l}\text { Develop cross-border e-commerce and promote the } \\
\text { development of global investment and trade }\end{array}$ & \\
\hline 2016.9 & $\begin{array}{l}\text { "G20 Digital Economy Development and } \\
\text { Cooperation Initiative" Hangzhou G20 } \\
\text { summit }\end{array}$ & $\begin{array}{l}\text { The world's first digital economy policy document, } \\
\text { which lists "digital economy" as an important topic } \\
\text { in the G20 innovative growth blueprint }\end{array}$ & \\
\hline 2017.3 & Government work report & $\begin{array}{l}\text { New terms such as artificial intelligence and digital } \\
\text { economy appeared in the report for the first time }\end{array}$ & 5 \\
\hline 2018.4 & $\begin{array}{l}\text { National Conference on network security } \\
\text { and informatization }\end{array}$ & $\begin{array}{l}\text { Strengthen cooperation with countries along "The } \\
\text { Belt and Road Initiative," and build digital silk road } \\
\text { in twenty-first Century }\end{array}$ & \\
\hline 2019.10 & $\begin{array}{l}\text { "Implementation Plan of National Digital } \\
\text { Economy Innovation and Development Pilot } \\
\text { Zone" }\end{array}$ & $\begin{array}{l}\text { Six national digital economy innovation and } \\
\text { development pilot zones have been awarded, } \\
\text { focusing on building a benchmark for China's } \\
\text { digital economy innovation and development }\end{array}$ & \\
\hline 2020.11 & $\begin{array}{l}\text { "Regional Comprehensive Economic } \\
\text { Partnership Agreement" (RCEP) }\end{array}$ & $\begin{array}{l}\text { The agreement included digital trade topics such as } \\
\text { telecommunications and e-commerce, making them } \\
\text { be important fields of high-level open cooperation } \\
\text { among the agreement countries }\end{array}$ & $\begin{array}{l}\text { Table 1. } \\
\text { of China's }\end{array}$ \\
\hline 2021.3 & Government work report & $\begin{array}{l}\text { Promote digital industrialization and industrial } \\
\text { digital transformation, and accelerate the } \\
\text { construction of a digital society }\end{array}$ & $\begin{array}{r}\text { digital economy } \\
\text { policies related to } \\
\text { foreign trade }\end{array}$ \\
\hline
\end{tabular}

economy has changed the traditional form of trade, and new business forms and new businesses are emerging. Additionally, the development of China's digital economy promotes industrial innovation and absorbs a large amount of labor employment. Qi et al. (2020) analyzed the impact and mechanism of digital economy development on employment structure and employment quality. They found that digital economy development will optimize employment structure, improve labor remuneration and strengthen labor protection. The "White Paper on China's Digital Economy Development and Employment (2019)" showed that in 2018, China's digital economy provided 191 million jobs, representing $24.6 \%$ of total employment, with a year-on-year increase of $11.5 \%$, which was significantly higher than the national total employment growth in the same period. At the same time, the continuous accumulation of China's human capital is also the driving force for the digital economy's development. In recent years, colleges and universities have added professional directions, such as big data development, data mining, data analysis, machine learning and cloud computing, to continuously cultivate excellent talents for developing the digital economy. These changes are also positive feedback for the healthy development of China's digital economy.

Under the conditions of resources, policies, technology and talents, China's digital economy is moving toward the comprehensive promotion of digital infrastructure, the deep integration with the real economy, and the continuous emergence of new formats and new models. The development of China's digital economy also provides rich soil for digital trade.

\section{Development status and characteristics of digital trade}

Since the fourth industrial revolution [2], the worldwide trade pattern and economic environment have constantly been changing. With the in-depth understanding of the concept of digital economy, the connotation of digital trade, as the expansion of digital economy in the field of trade, is also changing (Zhang and Jiang, 2021). The China Academy of Information and Communications Technology (CAICT) defines "digital trade" as "a trade form in which digital technology plays an important role," including the digitization of trade objects and 
$\underset{2,1}{\text { JIDE }}$

6

modes. The research on digital trade theory started later in China than in abroad (Chen and Zhu, 2019). With the rapid development of digital economy, digital trade is not only a new direction of global trade, but also a new force of China's economic growth. At present, China's digital economy has gradually integrated with the real economy. With the continuous development of the new form of the digital economy, China's advantages in developing digital trade are prominent. In 2020, China's export of digital services such as e-commerce, social media, communication services and digital information grew strongly. According to the United Nations Conference on Trade and Development (UNCTAD) data, from 2015 to 2019, China's digital trade scale increased from 179.44 billion US\$ to 271.81 billion US\$, with an average annual growth of $11.4 \%$. Among them, the proportion of service trade increased from 27.4 to $34.7 \%$. Developing digital trade is an essential means to promote sustainable economic development in China. Based on the technical characteristics and development of digital economy, digital trade also has some characteristics different from traditional trade forms. Next, this paper will summarize a series of digital trade characteristics.

\subsection{Digital trade has the characteristics of low cost}

With the gradual expansion of the scale of digital economy all over the world, digital trade attached to digital platform and technology has the characteristics of low cost. In terms of transportation costs, the gravity model in traditional trade theory points out that transportation distance affects trade cooperation; however, digital trade has almost no transportation cost (Gomez-Herrera et al., 2014; Ma et al., 2019; Wu and Yang, 2019). Due to the convenience of information collection, data transportation and communication, the cost of digital trade will be lower than that of traditional trade (Tambe et al., 2012; Huang et al., 2019; Qi and Ren, 2020). Among them, digital platform services provide effective support for the digital economy and digital trade. Guo and Qiu (2020) pointed out that under the background of the digital economy, video conference, AR technology, VR technology and real-time translation can help realize international long-distance commuting and save costs for digital trade. In addition, the rapid expansion of $5 \mathrm{G}$ communication and blockchain technology in China also provides a safe and efficient platform for digital trade development.

In terms of product attributes, the characteristics of strong replicability and low marginal cost of digital products also make them have significant low-cost characteristics in many aspects such as product production, sales, dissemination and certification (Fournier, 2014; Zhang and Jiang, 2021). Gonzalez and Jouanjean (2017) believed that digital trade could reduce information asymmetry, facilitate the matching of supply and demand and reduce costs. Goldfarb and Tucker (2019) found that the digital economy has dramatically reduced the cost of information, almost to zero, and Brouthers et al. (2016) found that digital companies create value through network effects.

\subsection{Europe and the USA currently dominate the digital trade market}

Over the past decade, China has attached great importance to the development of digital economy, and relevant supporting policies have been intensively introduced. However, compared with Europe and the USA, China still started late. At present, the digital trade market is still dominated by Europe and the USA. In terms of trade share, the "White Paper on the Digital Trade Development (2020)" showed that in 2019, the export scale of digital services of developed economies, developing economies and transition economies were 243.1 billion, 720.39 billion and 41.19 billion, respectively (in US\$). The USA, Britain, Ireland, Germany and the Netherlands accounted for nearly $50 \%$, and the USA alone accounted for $16.7 \%$. There is still a worldwide imbalance in the development of digital trade. The decentralization of market participation in digital trade and regional imbalance still restrict the development of the global digital economy. On one hand, this is affected by the infrastructure construction and network 
information technology of various countries. The "World Internet Development Report (2020)" evaluated 48 countries and regions globally from the dimensions of infrastructure, innovation capability, industrial development, Internet application, network security and network governance. The results showed that the internet development in the USA, China and Germany ranks among the top three, and there is still significant room for progress in the internet development of Latin America and Africa. On the other hand, the endogenous characteristics of data elements in the digital economy may make the digital economy present the characteristics of "self-strengthening" like a snow ball (Shapiro and Varian, 1998; Xie et al., 2019). Therefore, exporters in countries with large export scale and wide trading range can accumulate more data information through trading activities, which makes the development of digital trade also present a "Matthew effect". After that, this leading advantage can continuously strengthen its market position, and finally make the digital trade field show obvious characteristics of pioneer advantage and a highly monopolized market structure of "winner takes all".

From the perspective of rulemaking, Europe and the USA are still the leaders in formulating digital trade rules. For the consideration of information sovereignty and national interests, countries worldwide have put forward a series of rules for digital trade. Each trading country plays the dominant management game, and the main body of rulemaking gradually extends from developed countries to developing countries. Chen and Zhu (2019) summarized the digital trade rules in relevant agreements under the framework of the World Trade Organization (WTO) rules, such as "the General Agreement on Tariffs and Trade" (GATT), "the General Agreement on Trade in Services," and "Trade in Service Agreement"(TISA). In addition, there are regional and bilateral trade agreements among developed countries, such as the "TransPacific Partnership Agreement," the "Japan EU Free Trade Agreement” (Japan EU FTA), and "United States-Mexico-Canada Agreement." In the digital trade development process, the USA, the European Union and other developed countries have always been at the forefront, and they have an absolute voice in rulemaking. Some scholars summarized the situation as the "American template" and the "European template" (Chen and Zhu, 2019), which might restrict the healthy development of global digital trade.

\subsection{Rapid development of digital service trade}

The development of digital economy not only promotes industrial innovation, but also provides a large number of jobs. Thanks to the development of digital technology under the background of digital economy, many service industries have broken through the limitation of "non-tradable" to a certain extent, and service trade has developed rapidly and become an important part of the international trade system. The comparative advantage of labor endowment in developing countries can further promote the development of service trade (Guo and Qiu, 2020). With an increasing supply of skilled workers, a new business form of service trade may emerge in which workers commute long-distance. The dominant position of digital trade in service trade has gradually emerged, promoting the development of global trade to digital service. The "White Paper on the Digital Trade Development (2020)" showed that in 2019, the export scale of global digital service trade reached 3,192.59 billion US\$, accounting for $52.0 \%$ in service trade and $12.9 \%$ in total trade. UNCTAD data showed that digital service export's average annual growth rate reached $8 \%$ in the past decade, and more than half of the global service trade has adopted digitization. At present, China's digital trade is entering a new stage of rapid development. The "China Digital Trade Development Report (2020)," issued by the Research Institute of the Ministry of Commerce, pointed out that in 2019, China's total import and export of digital services reached 271.81 billion US\$, an increase of 4.56 times from 2005. If China wants to maintain this rapid development trend, it urgently needs responsible large countries to participate in the formulation of rules, such as transaction rules, currency use rules, tax rules, etc. Conversely, China needs to accelerate 

JIDE

8

innovation and cultivate high-quality digital service enterprises to cultivate new competitive advantages.

In general, developing the digital economy helps to promote the development of digital trade. Countries with strong digital economies have made tremendous gains in digital trade in recent years, and digital economies may provide future "corner overtaking" opportunities for developing countries. Under the rapid development of the digital economy, international trade presents a new development pattern. To use the development of the digital economy to promote the development of China's digital trade, we first need to clarify the challenges and comparative advantages of China's development of digital trade and find countermeasures.

\section{Challenges and comparative advantages of digital trade in China}

Digital trade is an integral part of the trade development of various countries and the carrier of the dispute over science, technology, rules and even dominance. Despite the escalating trade friction between China and the USA and the USA tightening its restrictions on China's high technology, China's digital trade development is still at the forefront of the world. China is rich in data resources and steadily advancing the construction of digital infrastructure, which has the necessary conditions for the development of digital trade. Absolute advantage theory, comparative advantage theory, neoclassical trade theory and finished goods trade theory proves that trade can increase national wealth. Among them, the trade interest margin between comparative advantage and trade cost is the trade driving force of each country. Therefore, only by clarifying the challenges and the comparative advantages of China's foreign trade in the new period can we ensure the sustainable growth of China's trade.

\subsection{Challenges faced by the development of China's digital trade}

4.1.1 Under the background of European and American dominance, China's core technology is restrained. Different countries have different degrees of digital trade development. Since the friction between China and the USA, the competition in science and technology has become increasingly fierce. Countries have issued corresponding development policies, showing that they attach great importance to its development. The competition for the dominance of international trade rules is a competition for interests. The international trade policies dominated by Europe and the USA will be more inclined to safeguard their own or related groups' interests. For example, they may manipulate oil prices to limit the development of energy shortage countries, promulgate intellectual property policies to protect developed countries' export interests, or adopt trade barrier policies, such as the "General Agreement on Textile and Fiber Trade," to restrict developing countries' textile exports. In neoclassical trade theory, there are no special technical barriers to product production. However, in the development of digital trade, technical barriers have gradually become an important obstacle in trade activities (Melitz, 2003; Helpman, 1981).

At present, there are still many shortcomings in the development of digital trade in China, such as lack of core competitiveness and low industrial concentration. Further breakthroughs are needed in core technology and technological autonomy. Some core technologies are still restrained. For example, some core components (such as chips) and system software (such as MATLAB) in China still rely on foreign imports, which will hinder the participation of countries and enterprises in production and trade activities. China is the world's largest chip importer, and chip design and manufacturing problems have affected China's position in the international market. For example, in 2019, the USA included Huawei in the export control list, and the supply chain blockage has seriously limited Huawei's further global development. Under the increasing uncertainty of the global macro environment and the advent of the antiglobalization wave, China's core digital economy technology is still facing a significant breakthrough, so it is urgent 
to improve the innovation ability. Therefore, China needs to turn passivity into initiative, strive for the voice in trade rules, develop core technology and improve innovation ability to ensure the interests of domestic manufacturers and economic development.

4.1.2 Under the background of European and American dominance, China's digital security faces challenges. Although China has ranked first in the world in terms of the digital economy's industrial competitiveness, there are still obvious weaknesses in digital security governance, which will seriously restrict China's long-term trade development. Digital trade depends on information and data, and data transmission involves the privacy of all nations. The measures and rules adopted by international governments to protect data privacy are different. The regulatory mechanisms for collecting, sharing and protecting consumer information are also quite different, potentially leading to friction or conflict between countries and reducing trade openness to some extent (Chen and Zhu, 2019; Ahmed, 2019). Data security includes two aspects, the first of which is algorithm ethics. Data containing personal privacy, which has inherent domestic data security problems, such as "big data discriminatory pricing" (varied prices for the same product or service based on different consumers) and "Information Cocoons" (meaning that the scope of information attention may be affected individuals' interest, which is easily limited to areas of personal attention or pleasure). The second aspect is cross-border data security, extended to international trade. For example, trade agreements, such as CPTPP and TISA, focus on intellectual property protection, cross-border data free flow and data privacy protection. Therefore, some countries have launched a new round of big country rule dominance games. Digital trade depends on information and data, and data transmission involves the privacy of all nations. Zheng and Zhao (2020) believed China lacks specific legal data flow and supervision regulations. The "White Paper on Future Economy (2021)" first proposed the concept of "digital trust," pointing out that cloud-native security is the core to building future digital trust, and artificial intelligence and blockchain will contribute to solving the problem of digital trust. Therefore, China should conduct in-depth research on digital trade theory and practice. When formulating rules, China should consider privacy protection and strive to eliminate digital trade barriers, provide a legal guarantee for China's digital security in global digital trade competition, strengthen the construction of digital security in foreign trade and find the Pareto optimality in data security and trade growth.

4.1.3 In the background of "digital divide", the unbalanced development of digital trade needs to be solved. Data elements are the basic conditions to ensure the growth of worldwide digital trade (Huang and Chen, 2021), but there is still an enormous digital divide among countries, regions and industries. The digital divide is a long-term challenge that countries must face in the period of digital transformation. Its essence can be defined as the difference in the ability to own, use and create information, including the amount of information, the popularity of the internet, the level of education, infrastructure construction, etc. UCTAD reported that during COVID-19, the digital economy had a significant impact on the economic recovery of all nations, and digital services such as telecommuting, telemedicine and digital education developed, and also provided support for trade activities. However, areas with a low degree of digitization do not enjoy the benefits of digitization, which may be affected by the improvement of digital infrastructure in different areas. The inequality caused by varying levels of digitization in various areas may be further amplified during the pandemic. The digital divide is a problem of unbalanced development. The expanding digital divide needs to be solved; otherwise, the resulting inequality and the gap between the rich and the poor will be further expanded, which will affect long-term regional development. Digital trade can promote the coordinated development of various regions, provide new economic development opportunities for developing areas, and realize the optimal allocation of resources. Therefore, while enjoying the digital dividend, China should increase the output of digital technology, encourage traditional industries to upgrade digitally and develop more 
digital products. In addition, China should vigorously support areas and industries with slow development of digital trade, so that vulnerable economies can also participate in global digital trade under the influence of the digital divide. Only by solving the digital divide issue can all areas share the development achievements of digital trade.

\subsection{Comparative advantages of China's digital trade development}

4.2.1 High productivity led by talent bonus. Low cost and high efficiency are the basis for the further development of digital trade (Jouanjean, 2019). Li et al. (2017) found that high-density information technology can improve total factor productivity in the manufacturing industry. Sturgeon (2019) found that digital technology can improve the modularity of the value chain, making it easier for traditional industries to realize inter-organizational and inter-regional collaboration through offshore outsourcing, improving industrial productivity. The "OECD Digital Economy Outlook 2020" showed that the digitization rate of production equipment and important processes in China's industrial enterprises were 49.4 and $51.7 \%$, respectively. Of 305 intelligent production pilot projects over 92 key industries, the average production efficiency has increased by $44.9 \%$. At present, the digital economy has gradually penetrated real industries. Compared with traditional trade, digital trade reduces the demand for labor and focuses more on production efficiency. High productivity led by talent bonus is a new comparative advantage of digital trade. In the past few decades, China's comparative foreign trade advantage was significant cheap labor resources. However, with the accelerated trend of aging and fewer children in China and other developing countries having extensive lowcost labor resources, China's traditional comparative foreign trade advantage has gradually weakened. With China's continuous progress in science and technology and the additional role of talent bonus, China's comparative advantage should evolve from low labor prices into high production efficiency in the new period. And this comparative advantage should be prioritized to promote the rapid development of China's foreign trade.

4.2.2 The ability of digital technology innovation. Although digital trade activities will face more technical barriers and patent barriers, the strong technology spillover and diffusion effects brought by lower learning costs in the digital trade environment also provide opportunities for late developing countries to catch up or even surpass (Zhang and Jiang, 2021). In recent years, new models and business forms of digital technologies, such as smart logistics, digital customs, blockchain, cloud computing and cloud outsourcing, have been emerging, mainly due to China's continuous development of its digital infrastructure construction, digital technology R\&D capacity and digital industry vitality. The new infrastructure, supported by information technology, can provide support for digital trade. The development of the digital economy is inseparable from the development of new digital technologies, such as 5G network communication, big data, artificial intelligence, etc., and China's mobile communication technology has achieved leapfrog development from 2G to 5G. The "Analysis of Digital Economy Situation in 2020-2021," released by the National Industrial Information Security Development Research Center, showed that China's 5G deployment has comprehensively accelerated, ranked first globally in construction speed and scale. He (2021) showed that China leads the world in the number of patents in artificial intelligence, such as voice, image and face recognition, and the gap between domestic and foreign advanced level CPUs is gradually narrowing. Therefore, China should continue to prioritize the comparative advantages of digital technology innovation, promote the further integration of advanced technology and foreign trade, and develop new digital trade models, such as medical security, intelligent education and ecological, environmental protection.

4.2.3 Broad growth potential of service trade. Countries worldwide regard the development of digital trade as a strategic starting point for a new round of competitive industrial advantage. The proportion of service trade in China's total foreign trade is still lower than the global 
average. In particular, there is an apparent gap in producer services between China and developed countries. From January to February in 2021, China's income from international goods and services trade, based on the international balance of payments, was 3,241.9 billion $\mathrm{RMB}$, expenditure was $2,682.5$ billion RMB and the surplus was 559.4 billion RMB. Among them, the revenue from trade in goods was 2,951.6 billion RMB, the expenditure was 2,303.9 billion $\mathrm{RMB}$ and the surplus was 647.7 billion RMB; the revenue from trade in services was 290.4 billion $\mathrm{RMB}$, the expenditure was 378.6 billion RMB and the deficit was 88.3 billion RMB. China has a large deficit with the USA regarding service trade, especially in service exports. China's service trade industry has a weak foundation and a low position in the global value chain, so there is still much room for improvement. Only by expanding the export of service trade can we change the balance of payments deficit and accelerate trade development. At present, China has accumulated some achievements in the digital service trade, such as establishing 105 comprehensive, cross-border, e-commerce pilot zones covering 30 provinces, regions and cities, and accelerating the outsourcing of productive services represented by online marketing promotion, biotechnology R\&D, inspection and testing. According to the "China Digital Trade Development Report (2020)," China's digital service trade has increased from 48.859 billion US\$ in 2005 to 271.81 billion US $\$$ in 2019 . In the past 15 years, the export volume has increased seven times, and the import volume has increased three times. China's digital service trade has broad prospects, and the country should take this opportunity to improve the development of the digital service trade. In recent years, China's emerging service trade has increased significantly, the deficit has been declining, the development environment of China's service trade has continuously optimized, and its strategic position has improved substantially. China should pay more attention to the export of digital service trade, fully combine the characteristics of digital trade and use its comparative advantages to improve its service trade competitiveness in the international field.

For a long time, China has profited in international trade from the advantage of low-cost labor through demographic dividends. However, this comparative advantage has gradually disappeared over time, and China urgently needs new comparative advantages to inject vitality into international trade. In the new era, international trade frictions are ongoing. China must clarify and transform the new comparative advantage to strive for the surplus position in international trade and realize economic growth.

\section{Countermeasures and suggestions}

In terms of economic aggregate and trade scale, China has the strength to compete with developed countries. The competition of international digital trade has become more and more intense. China should actively participate in the formulation of international rules, clarify its comparative digital trade advantages and release its potential to promote and increase its digital trade development. In order to better comply with the development of digital economy, it is imperative to give new judgments to the development of digital trade. This paper refers to the advanced experience of developed countries in building the digital economy and digital trade and proposes the following three suggestions.

\subsection{Break through core technical problems and strengthen innovation ability}

Reversing the passive situation that core technology is restrained as soon as possible is the top priority. First, improve the infrastructure construction required for digital trade, realize the optimal allocation of data resources and make use of talent bonus to promote efficient production. Second, grasp the priority in the development of China's digital trade, break through the core technical problems. Finally, accelerate digital technology innovation, transform traditional advantageous industries through digital technology, promote industrial digital transformation and build digital industrial clusters. 
JIDE

5.2 Participate in the formulation of international rules, and ensure data security

Accelerating the improvement of relevant laws and regulations in digital trade, actively participating in the formulation of international rules and promoting the integration of domestic policies and international agreement rules are the essential guarantees for developing the digital trade further. First, clarify the right to data privacy and control, ensure digital security, and improve the restrictions on digital flow security in multilateral and bilateral trade agreements. Second, strengthen the supervision of domestic, cross-border flow data, such as data security, financial information and personal privacy, form data protection laws and regulations with Chinese characteristics, and ensure national security and healthy economic development. Finally, in combination with the "The Belt and Road Initiative" development strategy, establish a digital trade policy with Chinese characteristics to attract more countries to integrate into China's digital trade cooperation circle to enhance China's global digital trade influence.

\subsection{Give priority to the development of service trade and improve the unbalanced development of digital trade}

With the gradual deepening of multilateral and bilateral cooperation on digital trade such as BRICs, G20, China-Russia and China-EU, it is a good time to adjust the trade structure and solve the problem of unbalanced development. First, optimize the structure of service trade, vigorously develop digital service trade, promote the construction of digital service export base and enhance international competitiveness. Second, vigorously support areas and industries with slow development of digital trade, so that vulnerable economies can also participate in global digital trade under the influence of the digital divide. Finally, build a global digital trading network, taking the "The Belt and Road Initiative" as an opportunity, and develop a digital trade cooperation community.

\section{Notes}

1. The author calculates and draws a conclusion according to the data from CAICT.

2. The fourth industrial revolution (since the beginning of the 21st century) focuses on artificial intelligence, clean energy, unmanned technology, quantum information technology, virtual reality and biotechnology, marking the entry of mankind into the era of green energy.

\section{References}

Ahmed, U. (2019), "The importance of cross-border regulatory cooperation in an era of digital trade", World Trade Review, Vol. 18, pp. 1-22.

Brouthers, K.D., Geisser, K.D. and Rothlauf, F. (2016), "Explaining the internationalization of ibusiness firms", Journal of International Business Studies, Vol. 47 No. 5, pp. 513-534.

Chen, W. and Zhu, S. (2019), "Research progress of digital trade theory and rules", Economic Perspectives, Vol. 9, pp. 114-126.

Fournier, L. (2014), "Merchant sharing toward a zero marginal cost economy", Papers.

Goldfarb, A. and Tucker, C. (2019), "Digital economics", Journal of Economic Literature, Vol. 57, pp. 3-43.

Gomez-Herrera, E., Martens, B. and Turlea, G. (2014), "The drivers and impediments for cross-border e-commerce in the EU", Information Economics and Policy, Vol. 28, pp. 83-96.

Gonzalez, J.L. and Jouanjean, M.A. (2017), “Digital trade: developing a framework for analysis”, Trade Policy Papers.

Guo, Z. and Qiu, Y. (2020), "Reconstruction of global value chain in the era of digital economy: typical facts, theoretical mechanism and China's strategy", Reform, Vol. 10, pp. 73-85. 
He, W. (2021), "Overview of the development of digital economy in China", Information and Communications Technology and Policy, Vol. 2, pp. 1-7.

Helpman, E. (1981), "International trade in the presence of product differentiation, economies of scale and monopolistic competition: a chamberlin-heckscher-ohlin approach", Journal of International Economics, Vol. 11 No. 3, pp. 305-340.

Huang, P. and Chen, L. (2021), "Construction of world economic operation mechanism and rules under digital economic globalization: from the perspective of factor flow theory", World Economy Study, Vol. 3, pp. 3-13.

Huang, Q., Yu, Y. and Zhang, S. (2019), "Internet development and productivity improvement of manufacturing industry: internal mechanism and China's experience", China's Industrial Economy, Vol. 8, pp. 5-23.

Jing, W. and Sun, B. (2019), "Digital economy promotes high-quality economic development: a theoretical analysis framework", Economist, Vol. 2, pp. 66-73.

Jouanjean, M.A. (2019), "Digital opportunities for trade in the agriculture and food sectors", OECD Food, Agriculture and Fisheries Papers, p. 122.

Li, J., Yu, D. and Zhang, M. (2017), "Information technology, total factor productivity and the dynamic mechanism of manufacturing transformation and upgrading - a study based on the "two departments" theory", Journal of Central University of Finance and Economics, Vol. 9, pp. 67-78.

Liu, S. (2019), "Targeted path and policy supply for high-quality development of China's digital economy", Economist, Vol. 6, pp. 52-61.

Ma, S., Fang, C. and Zhang, H. (2019), "Can cross-border e-commerce break through the limitation of geographical distance”, Finance and Trade Economics, Vol. 8, pp. 116-131.

Meijers, H. (2014), "Does the internet generate economic growth, international trade, or both?", International Economics and Economic Policy, Vol. 11 No. 1, pp. 137-163.

Melitz, M.J. (2003), "The impact of trade on intra-industry reallocations and aggregate industry productivity", Econometrica, Vol. 71, pp. 1695-1725.

Pei, C., Ni, J. and Li, Y. (2018), "Political economy analysis of digital economy", Finance and Trade Economy, Vol. 9, pp. 5-22.

Qi, J. and Ren, Y. (2020), “The development level of digital economy in the host country and China's foreign direct investment", The International Economic and Trade Exploration, Vol. 9, pp. 56-72.

Qi, Y., Liu, C. and Ding, S. (2020), "Development of digital economy, optimization of employment structure and improvement of employment quality", Economic Perspectives, Vol. 11, pp. 17-35.

Shapiro, C. and Varian, H.R. (1998), Information Rules: A Strategic Guide to the Network Economy, Harvard Business School Press, Boston.

Sturgeon, T.J. (2019), "Upgrading strategies for the digital economy", Global Strategy Journal, Vol. 11, pp. 1-24.

Tambe, P., Hitt, L.M. and Brynjolfsson, E. (2012), "The extroverted firm: how external information practices affect innovation and productivity", Management Science, Vol. 58 No. 5, pp. 843-859.

Wu, Q. and Yang, R. (2019), "Network and trade: a research framework of extended gravity model", Economic Research, Vol. 2, pp. 84-101.

Xie, F., Wu, Y. and Wang, S. (2019), "Political and economic analysis of platform economic globalization”, China Social Sciences, Vol. 12, pp. 62-81.

Zhan, X. and Ouyang, Y. (2018), "New trend of global investment under digital economy and China's new strategy of utilizing foreign capital", Journal of Management World, Vol. 3, pp. 78-86.

Zhang, Y. and Jiang, D. (2021), "International trade under digital economy: theoretical reflection and prospect", Tianjin Social Sciences, Vol. 03, pp. 84-92.

Zhang, X., Wan, G., Zhang, J. and He, Z. (2019), "Digital economy, inclusive finance and inclusive growth", Economic Research Journal, Vol. 8, pp. 71-86. 
JIDE

2,1

\section{Corresponding author}

Boning Li can be contacted at: liboning1994@163.com development path", Intertrade, Vol. 4, pp. 56-63. promoting the new development pattern of dual circulation", Intertrade, Vol. 2, pp. 12-18.

Zheng, W. and Zhao, Y. (2020), "Digital Trade: research on international trend and China's

\author{
Boningican becontactedat: libing1994@163.com
}

For instructions on how to order reprints of this article, please visit our website: www.emeraldgrouppublishing.com/licensing/reprints.htm Or contact us for further details: permissions@emeraldinsight.com 